\title{
The Relationship between Female EFL Students' Use of Reading Strategies and Their Reading Self-efficacy
}

https://doi.org/10.33806/ijaes2000.19.2.8

\author{
Zainab Alsuhaibani \\ Imam Mohammad Ibn Saud Islamic University, Saudi Arabia
}

\begin{abstract}
This study investigated the relationship between female EFL students' use of reading strategies and their reading self-efficacy. The participants were 191 female Saudi students majoring in English at Imam Mohammad Ibn Saud Islamic University. Two questionnaires; a reading strategy questionnaire and a reading self-efficacy questionnaire, and retrospective interviews were used to collect data of the study. The analysis of the data showed that female Saudi students used reading strategies at a moderate-frequency level. Problem-solving strategies were used more than global and support strategies. The students also showed a moderate sense of reading self-efficacy. The study further revealed that reading strategy use was significantly positively correlated with reading self-efficacy. A significant statistical difference between high self-efficacious students and low self-efficacious students in the overall use of reading strategies was found. The two groups further differed in the use of the subcategories of reading strategies. In addition, the study showed that the factors that affected students' reading self-efficacy beliefs were teachers' methodology in teaching and their encouragement and feedback, students' grades on exams, and students' ability to comprehend most of reading texts. The study recommends developing students' reading strategy use and reading selfefficacy beliefs while adopting a reading strategy instructional program.
\end{abstract}

Keywords: EFL reading self-efficacy, language learning, reading strategies, reading process.

\section{Introduction}

Reading strategies and reading self-efficacy beliefs are among the important factors in developing students reading ability. McCrudden, Perkins and Putney (2005: 120) stated that having self-efficacy and knowledge of strategies can provide students with the "will" and the "ways" when encountering challenging tasks. In fact, reading comprehension is a complex process influenced by many factors including cognitive and motivational factors (Sadeghi 2007). The use of reading strategies is one of the helpful means through which EFL readers can strengthen their reading comprehension. According to Kamran (2012) reading strategies are powerful learning tools that help readers deal with the problems that arise while reading a passage in a foreign language, consequently, improving individuals' reading comprehension. Motivational factors also play a major role in EFL reading comprehension. Randall (2008) confirmed that the state and the source of students' motivation are essential for understanding their course toward achievement in reading. As a motivational factor, self-efficacy beliefs greatly affect learners' performance and persistence when facing challenges. High self- 
efficacy beliefs in reading can help readers achieve better performance and overcome reading difficulties.

Given the significance of reading strategy use and reading self-efficacy, it is fundamental to know about the reading strategies used by Saudi EFL students and their self-efficacy beliefs in reading. Of equal importance is to understand the relationship between the use of reading strategies and reading self-efficacy. Grabe (2009) stated that explorations are needed with regard to the relationships between motivational traits and reading measures such as reading strategy use. Unlike studies on anxiety and attitudes, studies on reading self-efficacy are very few and scare in the EFL context, in particular. Zare and Mobarakeh (2011) asserted that although much research has been conducted on learning and reading strategies and self-efficacy beliefs in general, very little has explored the relationship between EFL reading self-efficacy and the use of reading strategies. This study is an attempt to explore this relationship through answering the following questions:

1. What are the reading strategies most often used by female Saudi EFL students when reading English academic materials?

2. What is the level of reading self-efficacy of female Saudi EFL students?

3. Is there a significant relationship between female Saudi EFL students' use of reading strategies and their reading self-efficacy beliefs?

4. Is there a significant difference between high self-efficacious readers and low self-efficacious readers in the use of reading strategies?

\section{Literature review}

Reading is a complex system of deriving meaning from print (McShane, 2005). This complex process involves intricate complexities associated with the constructing of meaning. During the last decades, several reading models emerged for the explanation of the reading process. The bottom-up, the top-down, and the interactive are three major models that have been widely discussed and applied in first and second language reading research. These models provide valuable foundational insight into the nature of reading, in general, and reading strategies, in particular.

The bottom-up model views reading as sequential mental process based on decoding the print (Gough, 1972). Readers start reading by decoding the letters, then the words, and they gradually progress toward larger linguistic chunks of phrases and sentences, ending eventually in meaning. The text, according to Gough, is a chain of isolated words, each of which is to be deciphered individually. Generally, this model considers the reading process to be a textbased and the reader decodes the text. With its overemphasis on the text and the decoding process, the bottom-up model underestimates the role of the readers' background knowledge. Grabe and Stoller (2011: 25) stated "bottom-up models suggest that all reading follows a mechanical pattern in which the reader creates a piece-by-piece mental translation of the information in the text, with little interference from the reader's own background knowledge". The perceived importance of the readers' background knowledge in processing the text led to the development of the top-down model. 
Unlike the bottom-up model, the top-down model is a reader-based model that stresses the role of the reader's knowledge, expectations and predictions. Goodman (1976), who developed this model, maintained that reading is a psycholinguistic guessing game and readers are active participants who use their background knowledge to guess meaning. They form hypotheses about which words they will encounter and take in just enough visual information to test their hypotheses. However, Purewal (2008) argued that the top-down model overemphasizes higher level processes assuming that learners have already mastered the lower level skills which is not the case, especially with poor readers and second language readers. The argument against the top-down model paves the way for the development of the interactive model.

The interactive model greatly influences the current understanding of the reading process. It is now commonly accepted as the representative picture of the reading process for both L1 and L2 readers (Anderson, 1999). Rumelhart (1994), who proposed the interactive model, suggested that reading is the product of simultaneous joint application of multiple knowledge sources that involves both "top-down" and "bottom-up" processing. In this line, Grabe and Stoller (2011) stated that reading is an interactive process in which linguistic information from the text interacts with the reader's long-term memory and his background knowledge. The theoretical assumptions of the interactive model with its combination of the bottom-up and top-down models form the basis for reading strategies.

Spurred by the significance of the reading comprehension process, reading strategies have generated great interest in the field of both first and second reading research. Basically, reading strategies can be defined as deliberate, goal-directed attempts aimed at modifying and controlling efforts to decode text, understand words, and construct meanings out of text (Afflerbach, Pearson and Paris 2008).

In fact, the importance of reading strategies has been recognized especially with regard to EFL academic success and reading comprehension. Abidin (2012) maintained that reading strategy is one of the fundamental factors in achieving success in the academic field. In the reading comprehension domain, several studies revealed that there is a relationship between reading comprehension and reading strategy use and that successful readers use reading strategies more frequently and effectively than less successful readers (Matar 1990; Sheorey and Mokhtari 2001; Sun 2010; Alsheikh 2011; Kamran 2012). In Karman's (2012) study, for example, a reading comprehension test and a survey of reading strategies were used to investigate the relationship between Iranian EFL learners' reading strategy use and their reading achievement. The analysis showed a statistically significant and positive relationship between the participants' reading comprehension and their overall use of reading strategies, global strategies and problem-solving strategies. Sheorey and Mokhtari (2001) examined the differences in the reported use of reading strategies of native and non-native English speakers when reading academic materials. The results revealed that both native and non-native high-reading-ability students show comparable degrees of higher reported usage for cognitive strategies and metacognitive strategies than 
lower-reading-ability students. Similarly, Rastegar, Kermani, and Khabir (2017) found a significant positive relationship between metacognitive reading strategies and students' TOFEL score in reading comprehension. In this regard, Malcolm (2012) commented that what appears to differentiate effective L2 readers from poor ones is their approach to tackling reading problems as they arise, drawing on their strategic reading knowledge to construct meaning from texts.

As a motivational factor, self-efficacy greatly influences learners' development in second or foreign language learning. Rahemi and Abedini (2009) affirmed that while the role of intellectual abilities in learning a foreign language cannot be denied, the notion that linguistic aptitude is the whole story seems to be controversial. They continued to say that the relevant literature supports the fact that aptitude can explain the differences among language learners only to some extent, thereby indicating the interference of other motivational factors. Similarly, Chastain (1988: 122) stressed that learners' beliefs play a larger role in developing second-language skills than the cognitive abilities "because the emotions control the will to activate or shut down the cognitive function". In the same vein, Bandura (1986) asserted that, of all beliefs, self-efficacy is the most influential one as it plays a powerful role in determining the choices people make, the effort they will persevere in the face of challenges and the degree of anxiety or confidence they will bring to the task at hand.

The notion of self-efficacy has its roots in Bandura's (1986) socio-cognitive theory, which suggests that a person's achievement is based on the interactions among the individual's behaviors, perceptions of self, and environmental influences. Within the socio-cognitive theory, Bandura (1997) defined selfefficacy as people's beliefs about their capabilities to learn or perform designated levels of performance required to manage prospective situations. Askar and Davenport (2009) also asserted that a person may possess the required knowledge and skills to perform a particular task, yet, he/she doesn't succeed because of selfdoubt, a lack of motivation, or other affective factors.

Due to this influence, self-efficacy plays an important role in student academic performance. Bong (2008) asserted that self-efficacy consistently predicts academic achievement. Margolis and McCabe (2006) explained that students with high self-efficacy are usually intrinsically motivated to face challenging tasks and exert great effort to succeed on them. On the other hand, students with low self-efficacy are less likely to make a concerted or extended effort and might not be able to persist during challenging tasks. They also have low aspirations in learning, which can result in disappointing academic performances. In the area of learning a foreign/second language, the effect of selfefficacy beliefs is also emphasized. Raoofi, Tan and Chan (2012) confirmed that self-efficacy is one of the most influential factors for L2 learning. It affects language learners' motivation and performance in different language domains.

Schunk (1995) identified several factors that affect students' self-efficacy beliefs in academic learning. These factors include information processing, encouragement and feedback, goal setting, and models. Information processing refers to students' beliefs about their capabilities to cognitively process academic 
materials that, in turn, influence their motivation and learning. Students with high self-efficacy beliefs persist and work harder on academic tasks; in doing so, they estimate how well they are doing. Knowing that they are processing the information successfully enhances their self-efficacy and motivation. In addition to information processing, encouragement and feedback support students' perceptions of their progress, sustain motivation, and increase efficacy for learning. Teachers who encourage students and provide them with positive feedback increase students' self-efficacy levels. Schunk further affirmed that linking students' success and achievements with effort (e.g., "You have been working hard") is fundamental and leads to a higher sense of motivation, selfefficacy, and skill more than stressing the need for exerting more effort ("You need to work hard"). Another factor affecting self-efficacy is goal setting. Students who have a goal might feel a sense of efficacy to attain that goal and work hard to achieve it. They engage in activities that lead to achieving their goals: attend to instruction, rehearse information to be remembered, expend effort, and persist during difficulties (Schunk 1995). Additionally, modeling is another factor that affects self-efficacy beliefs. Observing peer models' accomplishments conveys to observers that they, too, are capable of achieving success. This motivates them to work harder and increases their efficacy beliefs (Schunk 1995). Of equal importance is self-modeling which occurs when individuals watch replays of themselves performing tasks at their best. Thus, their beliefs of personal efficacy increase and their performance potentially improves (Bandura 1997).

Self-efficacy and reading strategies as motivational and cognitive factors, respectively, have their impact in developing students' reading skill. Unlike EFL reading strategies, reading self-efficacy research has received little attention. A few studies investigated the relationship between EFL reading proficiency and reading self-efficacy. Nevertheless, these studies proved the significance of reading self-efficacy in predicting EFL reading proficiency (Ghonsooly and Elahi, 2011; Mills, Pajares, and Herron, 2006; Morali 2019; Naseri and Zaferanieh 2012; Rachmajanti and Musthofiyah 2017; Sun 2010). In addition, there are scant studies that examined the relationship between EFL reading strategy use and reading self-efficacy. A general review of these studies is presented in this section.

A Chinese study carried out by Li and Wang (2010) explored the relationship between the use of reading strategies and reading self-efficacy. The participants were 182 sophomore EFL students. The analysis of the reading strategy questionnaire and the self-efficacy questionnaire revealed that the students felt confident in their abilities to complete reading tasks. They also used reading strategies at the medium level of frequency. Further, the results indicated that reading self-efficacy was significantly positively related to the overall use of reading strategies and the use of the three subcategories of reading strategies: metacognitive strategies; cognitive strategies; and social/affective strategies.

Similarly, Naseri and Zaferanieh (2012) examined the relationship between reading self-efficacy, reading strategies and reading comprehension of Iranian EFL university students. In their study, three instruments were used: a Michigan 
reading comprehension test, a reading strategy use questionnaire, and a reading self-efficacy questionnaire. The participants were $80 \mathrm{EFL}$ students. The results revealed strong and positive correlations between reading self-efficacy beliefs and reading comprehension as well as between reading self-efficacy beliefs and reading strategy use.

In contrast, Arum (2018) found little influence of self-efficacy in language learning strategies in reading among female students, and no relation among male students. However, it must be noted that the researcher collected his data through using a 25 -item questionnaire that contains only 5 items for self-efficacy, and 5 items for language learning strategies in reading.

From the abovementioned studies, a general positive correlation between EFL reading strategy use and reading self-efficacy has been found. Yet, other studies provide mixed findings. In addition, only quantitative measures were used to explore the relationship in these studies. Yet, there is a need for using qualitative measures to help verify the results of the correlation and understand the factors that affect reading self-efficacy beliefs. To do so, the present study combines both qualitative and quantitative instruments. A description of these instruments is followed.

\section{Methodology and procedures}

\subsection{Participants of the study}

The participants in this study were 191 female Saudi EFL students majoring in English at Imam Mohammad Ibn Saud Islamic University. They were freshmen students, ranging between 18 to 21 years old. Freshmen students were particularly chosen because they take courses dedicated mainly to developing English skills of reading, writing, listening /speaking and grammar, along with some Arabic courses.

\subsection{Research design}

A mixed-method research design incorporating both qualitative and quantitative instruments was used to address the questions of the study. The use of both types of instruments helped in getting a more in-depth analysis of the participants' reading self-efficacy beliefs and reading strategy use. It provides strengths that offset the weaknesses of both qualitative and quantitative instruments (Creswell and Clark 2010).

\subsection{Instruments of the study}

The instruments employed in this correlational study included two questionnaires and retrospective semi-structured interviews.

\subsubsection{Questionnaires}

Two questionnaires were used in the current study: a reading strategy questionnaire and a reading self-efficacy questionnaire. Prior to choosing the reading strategy questionnaire, the researcher conducted a group interview with 17 students not involved in the actual study. The aim of the group interview is to 
obtain a general view about the strategies students use in reading to help in choosing an appropriate questionnaire. Based on the results obtained from the group interview, the researcher decided to adapt Mokhtari and Sheorey's (2002) Survey of Reading Strategies (SORS). SORS is used to measure the type and frequency of reading strategies that non-native speakers of English use while reading academic materials in English. It consists of 30 items rated on a 5-point Likert scale that ranges from 1 ("I never or almost never do this") to 5 ("I always or almost always do this"). These 30 items measure three broad categories of reading strategies: global strategies (13 items), problem solving strategies (8 items), and support strategies (9 items). SORS was chosen to be used in this study due to its comprehensiveness in terms of the three dimensions of reading strategies. Further, SORS has been employed in many studies in different parts of the world which would allow for having comparative results among different cultures in terms of reading strategy use. Some minor modifications were made to the questionnaire items, such as changing "my mother tongue" to Arabic. In addition, an open-ended question was added to the survey to elicit other strategies the participants use while reading academic materials in English.

The second questionnaire was the reading self-efficacy questionnaire, which was used to solicit information regarding participants' beliefs in their own reading capabilities. Some of the questionnaire's items (1-7) were based on selected items from previous studies (Rahimi and Abedini 2009; Sun 2010; Ghonsooly and Elahi 2011). The other items, 8 in number, were developed after a thorough review of the literature. The reading self-efficacy questionnaire included 15 items to which the participants responded using a 5-point Likert scale ranging from 1 (strongly disagree) to 5 (strongly agree).

The two questionnaires were validated by professors in applied linguistics. Their comments and modifications were taken into consideration. The questionnaires, then, were pilot tested on a representative of 19 freshman EFL students not involved in the actual study. Cronbach's alpha test was run to measure the internal consistency and the reliability of the questionnaires.

\subsubsection{Retrospective semi-structured interviews}

The interviews were conducted to confirm the results of the quantitative data with regard to the frequency and the types of the reading strategies used. They also explored what the participants actually did in order to understand the passage and what specific strategies they used. In addition, they explained the results of the participants' reading self-efficacy in the light of the factors that affected their selfefficacy beliefs. Wenden and Rubin (1987) stated that readers' interviews are generally extremely productive concerning strategy use. The best way to know what strategies participants actually use as they read is to ask them. Retrospective interviews also have the advantage of providing the actual strategies used without relying on the inferences of the participants. Meanwhile, they do not interfere with the normal reading process as in concurrent think aloud technique (Camps 2003).

Four participants from the high self-efficacy group and four participants from the low self-efficacy group were interviewed based on the results of the 
reading self-efficacy questionnaire and the participants' willingness to participate. Each interviewee was given a reading passage and was then interviewed with the researcher. The researcher also observed the participants while they were reading and took notes of what they did. The reading passage and the interview questions were validated and pilot-tested before being administered. The reading passage was titled "Animal Communication", written by Todd Hales (2005). The passage was chosen because of its familiarity and its interesting topic to the participants. The passage also had a readability score of around 51.0 (fairly difficult) as measured by the Flesch Reading Ease test. The interview questions that followed reading the passage were five main questions along with follow-up questions. They were designed to elicit information about the strategies the interviewees used while reading the passage, and to probe into the factors that affected their self-efficacy beliefs in reading. The interviews were tape-recorded and transcribed in order to be analyzed.

\subsection{Procedures}

The researcher personally administered the instruments of the study. The two questionnaires were distributed together. The researcher told the participants that their identities would be kept confidential and that their participation would help in improving the learning and teaching of reading. The questionnaires were completed within about 15 minutes. The data were analyzed after the removal of incomplete questionnaires. Two weeks later, four participants from the high selfefficacy group and four participants from the low self-efficacy group were selected to be interviewed. The interviewees were informed that the interviews would be tape-recorded for research purposes only. They were ensured anonymity and confidentiality. Two of them refused. Therefore, another two participants were selected. The researcher arranged a suitable time with each interviewee to be interviewed. Upon meeting, the interviewee was given the reading passage and was requested to use any resources or tools (such as paper or electronic dictionaries, pencils, highlighters, etc.) that she would normally use when reading for academic purposes. During this period, the researcher observed and took notes of the interviewee's actions. The retrospective interview was conducted immediately after the participant finished reading the passage. The researcher asked the interview questions; and the interviewee's responses guided subsequent questions. The interviews were transcribed and translated soon afterward.

\section{Results and discussion}

\subsection{Quantitative data results}

In order to identify the reading strategies that are most often used by female Saudi EFL students in reading English academic materials, descriptive statistics of the reading strategy questionnaire were run. Generally, the results (see Table 1) showed that the students reported using reading strategies at a moderate-frequency level $(M=3.42)$. Problem-solving strategies showed the highest mean $(M=3.74)$ among the three subcategories. Global and support strategies were reported to be used at a very similar frequency ( $M=3.26$ and $M=3.25$, respectively). 
Table 1. Means and standard deviations of reading strategy use

\begin{tabular}{|l|l|l|l|l|}
\hline $\begin{array}{l}\text { Mean and } \\
\text { standard } \\
\text { deviation }\end{array}$ & $\begin{array}{l}\text { Overall } \\
\text { strategy use }\end{array}$ & $\begin{array}{l}\text { Problem-solving } \\
\text { strategy }\end{array}$ & $\begin{array}{l}\text { Global } \\
\text { strategy }\end{array}$ & $\begin{array}{l}\text { Support } \\
\text { strategy }\end{array}$ \\
\hline $\mathrm{M}$ & 3.4200 & 3.7412 & 3.2631 & 3.2556 \\
\hline $\mathrm{SD}$ & .53165 & .68032 & .54086 & .64315 \\
\hline
\end{tabular}

Specifically, the top five reported strategies from the reading strategy questionnaire were one global strategy, one support strategy, and three problemsolving strategies (see Table 2). The global strategy was "I use tables, figures, and pictures in text to increase understanding" ( $M=4.32$.). The support strategy was "I underline or circle information in the text to help me remember it" $(M=4.10)$. The three problem solving strategies were "When text becomes difficult, I re-read it to increase my understanding" $(M=4.06)$, "I try to get back on track when I lose concentration" $(M=3.97)$, and "I read slowly and carefully to make sure I understand what I am reading" $(M=3.91)$. Having three problem-solving strategies among the most used strategies supports the finding that the participants used problem-solving strategies most frequently.

Table 2. Means of the top five strategies

\begin{tabular}{|l|l|l|}
\hline Category & Strategy & Mean \\
\hline $\begin{array}{l}\text { Global } \\
\text { strategy }\end{array}$ & $\begin{array}{l}\text { I use tables, figures, and pictures in text to increase } \\
\text { understanding }\end{array}$ & 4.32 \\
\hline $\begin{array}{l}\text { Support } \\
\text { strategy }\end{array}$ & $\begin{array}{l}\text { I underline or circle information in the text to help me } \\
\text { remember it }\end{array}$ & 4.10 \\
\hline & $\begin{array}{l}\text { When text becomes difficult, I re-read it to increase my } \\
\text { understanding }\end{array}$ & 4.06 \\
\cline { 2 - 3 } $\begin{array}{l}\text { Problem- } \\
\text { solving } \\
\text { strategy }\end{array}$ & I try to get back on track when I lose concentration & 3.97 \\
\cline { 2 - 3 } & $\begin{array}{l}\text { I read slowly and carefully to make sure I understand what } \\
\text { I am reading }\end{array}$ & 3.91 \\
\hline
\end{tabular}

Descriptive statistics were also calculated to determine the mean of the reading self-efficacy questionnaire. Table 3 below shows that the mean score of reading self-efficacy questionnaire was 3.49, indicating an acceptable level of reading self-efficacy beliefs among students. In other words, participants, on average, had a moderate sense of reading self-efficacy. 
Table 3. Mean and standard deviation of reading self-efficacy

\begin{tabular}{|l|l|}
\hline Mean and standard deviation & Self-efficacy \\
\hline $\mathrm{M}$ & 3.4977 \\
\hline $\mathrm{SD}$ & .50893 \\
\hline
\end{tabular}

To investigate the relationship between reading strategy use and reading self-efficacy beliefs, calculations of correlation coefficients were run. The calculations revealed that reading strategy use was significantly positively correlated with reading self-efficacy (see Table 4). Specifically, significant positive correlations were found between reading self-efficacy and the overall use of reading strategies $(r=0.45, p<.01)$, and between reading self-efficacy and the subcategories of reading strategies: problem-solving strategies $(r=0.56, p<.01)$, global strategies $(r=0.42, p<.01)$ and support strategies $(r=0.39, p<.01)$.

Table 4. Correlations between reading self-efficacy and overall use of reading strategy, problem-solving strategies, global strategies, and support strategies

\begin{tabular}{|l|l|l|l|l|}
\hline $\begin{array}{l}\text { Reading strategy } \\
\text { use }\end{array}$ & $\begin{array}{l}\text { Overall } \\
\text { reading } \\
\text { strategy use }\end{array}$ & $\begin{array}{l}\text { Problem- } \\
\text { solving } \\
\text { strategies }\end{array}$ & $\begin{array}{l}\text { Global } \\
\text { strategies }\end{array}$ & $\begin{array}{l}\text { Support } \\
\text { strategies }\end{array}$ \\
\hline $\begin{array}{l}\text { Reading self- } \\
\text { efficacy }\end{array}$ & $.45 * *$ & $.56 * *$ & $.42 * *$ & $.39 * *$ \\
$* * p<.01$ & & & \\
\hline
\end{tabular}

To find out whether there is a significant difference between high selfefficacious readers and low self-efficacious readers in the use of reading strategies, independent sample $t$-tests were computed. The median (3.35) was used as the cut-off criterion to set aside high self-efficacious readers from low self-efficacious readers. Table 5 reveals that high self-efficacious readers $(N=97)$ reported higher reading strategy use $(M=3.55)$ than low self-efficacious readers $(N=94, M=3.27)$. Furthermore, the difference between high self-efficacious readers and low self-efficacious readers was found to be statistically significant at the 0.05 level (2-tailed) $(t(189)=-4.015, p=.000$.). 
Table 5. Difference between high and low self-efficacious readers in overall reading strategy use

\begin{tabular}{|c|c|c|c|c|c|c|c|}
\hline $\begin{array}{l}\text { Reading } \\
\text { strategies }\end{array}$ & Group & $\mathrm{N}$ & $\mathrm{M}$ & SD & $\mathrm{T}$ & Df & Sig \\
\hline \multirow{2}{*}{$\begin{array}{l}\text { Over all } \\
\text { reading } \\
\text { strategies }\end{array}$} & $\begin{array}{l}\text { High self- } \\
\text { efficacious } \\
\text { readers }\end{array}$ & 97 & 3.5588 & .45046 & \multirow{2}{*}{$\begin{array}{l}- \\
4.015\end{array}$} & \multirow{2}{*}{189} & \multirow{2}{*}{.000} \\
\hline & $\begin{array}{ll}\text { Low } & \text { self- } \\
\text { efficacious } & \\
\text { readers } & \end{array}$ & 94 & 3.2764 & .51999 & & & \\
\hline
\end{tabular}

More specifically, the difference between high self-efficacious readers and low self-efficacious readers in terms of the subcategories of reading strategy is presented in Table 6 . As indicated by the table, high self-efficacious readers reported using more strategies in all of the subcategories of reading strategy than the low self-efficacious readers. The high self-efficacy group reported using problem-solving strategies most frequently, followed by global strategies, then support strategies. On the other hand, the low self-efficacy group reported using problem solving strategies most frequently, followed by support strategies, and finally global strategies. The differences between the two groups in problemsolving strategies and global strategies were found to be statistically significant at the 0.05 level (2-tailed). However, the difference between the two groups in terms of support strategy was not statistically significant $(p>0.05)$. 
Table 6. Differences between high self-efficacious readers and low selfefficacious readers in the use of the three subcategories of reading strategies

\begin{tabular}{|c|c|c|c|c|c|c|c|}
\hline $\begin{array}{l}\text { Reading } \\
\text { strategies }\end{array}$ & Group & $\mathrm{N}$ & M & SD & $\mathrm{T}$ & Df & Sig \\
\hline \multirow{2}{*}{$\begin{array}{l}\text { Problem- } \\
\text { solving } \\
\text { strategies }\end{array}$} & $\begin{array}{l}\text { High self- } \\
\text { efficacious } \\
\text { readers }\end{array}$ & 97 & 3.9626 & .53405 & \multirow{2}{*}{-4.945} & \multirow{2}{*}{189} & \multirow{2}{*}{.000} \\
\hline & $\begin{array}{l}\text { Low self- } \\
\text { efficacious } \\
\text { readers }\end{array}$ & 94 & 3.5253 & .68160 & & & \\
\hline \multirow{2}{*}{$\begin{array}{l}\text { Global } \\
\text { strategies }\end{array}$} & $\begin{array}{l}\text { High self- } \\
\text { efficacious } \\
\text { readers }\end{array}$ & 97 & 3.4044 & .49520 & \multirow{2}{*}{-3.877} & \multirow{2}{*}{189} & \multirow{2}{*}{.000} \\
\hline & $\begin{array}{l}\text { Low self- } \\
\text { efficacious } \\
\text { readers }\end{array}$ & 94 & 3.1088 & .55749 & & & \\
\hline \multirow{2}{*}{$\begin{array}{l}\text { Support } \\
\text { strategies }\end{array}$} & $\begin{array}{l}\text { High self- } \\
\text { efficacious } \\
\text { readers }\end{array}$ & 97 & 3.3093 & .63185 & \multirow{2}{*}{-1.298} & \multirow{2}{*}{189} & \multirow{2}{*}{.196} \\
\hline & $\begin{array}{l}\text { Low self- } \\
\text { efficacious } \\
\text { readers }\end{array}$ & 94 & 3.1950 & .58380 & & & \\
\hline
\end{tabular}

\subsection{Qualitative data results}

\subsubsection{Results of the open-ended question in the reading strategy questionnaire}

Few participants (\%28) responded to the open-ended question in the reading strategy questionnaire. In addition, some responses were actually paraphrases of the reading strategy items already stated in the questionnaire. However, some participants mentioned other reading strategies they used in reading English academic materials such as drawing diagrams and mind maps, consulting the internet for further explanation of difficult points, requesting assistance from a teacher or a friend, and writing outlines to increase understanding.

\subsubsection{Results of retrospective semi-structured interviews}

The eight interviewees (four high self-efficacious readers and four low selfefficacious readers) were asked about the strategies they used while reading the passage. Table 6 on the following page presents the different strategies used and how many interviewees used them. Participants from both groups used the three subcategories of the reading strategies. Specifically, they used seven problemsolving strategies, five support strategies, and four global strategies. Problemsolving strategies were used 14 times by high self-efficacious readers and 10 times by low self-efficacious readers. Support strategies were used 8 times by 
high self-efficacious readers and 6 times by low self-efficacious readers. Global strategies were used 7 times by high self-efficacious readers and 4 times by low self-efficacious readers.

Table 7. Interview results of the use of reading strategies by high and low selfefficacious readers

\begin{tabular}{|c|c|c|c|}
\hline $\begin{array}{l}\text { Strategy } \\
\text { categories }\end{array}$ & Reading strategies & $\begin{array}{l}\text { High self- } \\
\text { efficacious } \\
\text { readers }\end{array}$ & $\begin{array}{l}\text { Low self- } \\
\text { efficacious } \\
\text { readers }\end{array}$ \\
\hline $\begin{array}{l}\text { Problem- } \\
\text { solving } \\
\text { strategies }\end{array}$ & $\begin{array}{l}\text { Careful and slow reading } \\
\text { Speed adjustment } \\
\text { Rereading } \\
\text { Paying closer attention to difficult } \\
\text { parts } \\
\text { Guessing the meaning of unknown } \\
\text { words } \\
\text { Getting back on track when losing } \\
\text { concentration Stopping from time to } \\
\text { time for thinking }\end{array}$ & $\begin{array}{l}2 \\
1 \\
4 \\
2 \\
3 \\
1 \\
1\end{array}$ & $\begin{array}{l}2 \\
1 \\
4 \\
1 \\
2 \\
0 \\
0\end{array}$ \\
\hline & & Total: 14 & Total: 10 \\
\hline $\begin{array}{l}\text { Support } \\
\text { strategies }\end{array}$ & $\begin{array}{l}\text { Note taking } \\
\text { Using reference materials } \\
\text { Underlining } \\
\text { Finding relationships among ideas } \\
\text { Translation into Arabic }\end{array}$ & $\begin{array}{l}1 \\
2 \\
2 \\
1 \\
2\end{array}$ & $\begin{array}{l}1 \\
0 \\
2 \\
0 \\
3\end{array}$ \\
\hline & & Total: 8 & Total: 6 \\
\hline $\begin{array}{l}\text { Global } \\
\text { strategies }\end{array}$ & $\begin{array}{l}\text { Previewing text characteristics } \\
\text { Background knowledge (schemata) } \\
\text { activation } \\
\text { Overall viewing and skimming } \\
\text { Looking at pictures and figures to } \\
\text { increase understanding }\end{array}$ & $\begin{array}{l}1 \\
2 \\
2 \\
2\end{array}$ & $\begin{array}{l}2 \\
0 \\
0 \\
2\end{array}$ \\
\hline & & Total: 7 & Total: 4 \\
\hline
\end{tabular}

As Table 7 clearly shows, problem-solving strategies were the most used strategies in both groups. The table also reveals that high self-efficacious readers used more and different reading strategies. These results confirm the findings of the quantitative data. More importantly, by observing and interviewing the participants, the researcher found that high self-efficacious readers used strategies more effectively. For example, with regard to translation into Arabic, high selfefficacious readers demonstrated that they knew when and why to translate. They only translated the important words that led to a better understanding. On the other hand, low self-efficacious readers spent a lot of time translating even 
unimportant words. Thus, they wasted their time and were distracted from the main purpose of comprehending the passage. Furthermore, high self-efficacious readers knew which strategies to use in order to correctly identify the main idea of the reading passage. While some low self-efficacious readers focused mainly on the introduction to get the main idea and, as a result, identified it incorrectly.

Furthermore, the interviewees were asked about their judgments of their ability in reading and the reason behind their judgments in order to probe into the factors that affected their reading self-efficacy beliefs. High self-efficacious readers, on the whole, judged their reading ability in English as excellent and good. While the low self-efficacious readers used phrases such as "okay", "not that good" and "have an acceptable level" to describe their reading ability. When asked about the reasons behind their judgments, five interviewees (two high selfefficacious readers and three low self-efficacious readers) mentioned the role of teachers; their methods of teaching, and their encouragement and feedback. Three interviewees (two high self-efficacious readers and one low self-efficacious reader) mentioned their marks and grades. Two interviewees (both high selfefficacious readers) mentioned the fact that they can read and understand most reading texts, including difficult and long ones.

\subsection{Discussion}

The results of the study demonstrated that Saudi female EFL students used reading strategies in reading academic materials at a moderate-frequency level. These findings are consistent with those of Al-Nujaidi (2003), Elashhab (2008), Park (2010), Dhanapala (2010) and Temur and Bahar (2011). The moderate use of reading strategies is understandable because reading instruction in most Saudi EFL reading classes ignores the importance of reading strategies. Al-Onazi (2011) stated that despite recognizing strategy instruction as an efficient tool in enhancing students' metacognitive awareness of the interactive nature of the reading process, our EFL reading classes still disregard strategy instruction. Teachers may mention these strategies but they rarely model or illustrate their use practically, and learners may have no chance of practicing them sufficiently. The results also indicated that problem-solving strategies were the most used strategies among the three subcategories of reading strategy. Similarly, Atari (2003) found that EFL Saudi students employed such localized bottom-up, language-based strategies predominately. Using problem-solving strategies most frequently can be illustrated by the fact that they are localized strategies that require the reader to interact with the text only. Unlike global and support strategies, problem-solving strategies enable readers to comprehend the text in direct ways by, for example, rereading, adjusting their reading speed, or guessing the meaning of unknown words.

The results also showed that Saudi female EFL students had a moderate sense of reading self-efficacy. This indicates that the students felt relatively confident in their abilities in reading. Being L2 learners can explain, to some extent, the students' moderate sense of reading self-efficacy. Oxford and Shearin (1994: 21) commented that "many L2 students do not have an initial belief in their 
own self-efficacy". Moreover, few teachers try to raise EFL students' self-efficacy beliefs by encouraging them or giving them positive feedback, which they need to enhance their motivation and development.

Additionally, a significant positive correlation was found between reading strategy use and reading self-efficacy. Such a positive correlation echoes findings from previous research ( $\mathrm{Li}$ and Wang 2010; Sun 2010; Zare and Mobarakeh 2011; Naseri and Zaferanieh 2012). It further suggests that a stronger sense of selfefficacy is associated with a stronger use of reading strategies, because selfefficacy beliefs determine the choices and effort the student puts forth to comprehend the reading text. This illuminates the significance of and the need for the motivational role of self-efficacy in strategy use.

Moreover, the results indicated a significant difference between high selfefficacious readers and low self-efficacious readers in terms of reading strategy use. Students with high self-efficacy used strategies more frequently and effectively. This is in agreement with the findings of Li and Wang (2010) and Heidari, Izadi and Ahmadian (2012). According to Fan and Williams (2009) students with high self-efficacy are more likely to experience less self-doubt, exercise greater effort, and persist when facing difficulties. Meanwhile, students with low self-efficacy do not exert much effort, are less likely to try and attempt solving problems, and quickly give up.

Differences were also found between the two groups in the use of the subcategories of reading strategies. Students with high self-efficacy used global strategies more than support strategies. Conversely, students with low-selfefficacy used support strategies more than global strategies. Given that global strategies are more challenging and demanding strategies that require careful and intentional planning, students with high self-efficacy were willing to exert efforts to use them. On the other hand, students with low self-efficacy sought "support" from other sources, such as English-Arabic dictionaries and reference materials. In a similar vein, Mebarki (2011) found that high achievers used more global reading strategies than low-achievers.

With regard to the factors that affected students' reading self-efficacy beliefs, the participants of this study mentioned teachers' methodology in teaching and their feedback and encouragement, grades on exams, and the students' ability to comprehend most reading texts even long and difficult ones. Essentially, the role of the teacher in general and his/her encouragement and feedback are emphasized in self-efficacy beliefs (Schunk 1995). One interviewee stated, "I began to love reading and read a lot this semester because of our teacher. Her method of teaching and encouragement made me work harder and develop my reading ability". Exam grades are another factor that comes under self-modeling (Bandura 1997). The students can see their levels on grades and exams, which in turn affects their self-efficacy beliefs. When one of the interviewees was asked why she thought that she was not that good in reading, she said "I always get low marks in reading exams". Furthermore, students' ability to read and comprehend long novels and difficult texts increases their reading self-efficacy. This comes under the information processing factor (Schunk 1995). Knowing that they are 
able to process the information of long and difficult texts enhances their selfefficacy beliefs about reading. One interviewee judged her reading ability as excellent; when asked why, she said, "I got high grades in all my reading courses and I find myself able to read long novels and still understand them".

\section{Conclusion and pedagogical implications}

\subsection{Conclusion}

This study contributed to the understanding of the relationship between Saudi female EFL students' use of reading strategies and their reading self-efficacy. The results of the study showed that female Saudi EFL students used reading strategies at a moderate-frequency level, with problem-solving strategies being the most used strategies. They also had a moderate sense of reading self-efficacy. A significant positive correlation between reading strategy use and reading selfefficacy was also found. The study further revealed a significant difference between high self-efficacious readers and low self-efficacious readers in reading strategy use.

\subsection{Pedagogical implications}

The results of the study imply that developing students' reading strategies and fostering their reading self-efficacy beliefs are needed in reading instruction. As Saudi EFL students progress to higher academic levels, they are required to read more and more academic reading materials from different resources. Accordingly, a moderate use of reading strategies might not be enough. From the very beginning, teachers should emphasize reading strategy instruction to help students develop more frequent use of reading strategies. Also, as was shown in this study, some students were aware of some reading strategies but did not know how to use them effectively. Thus, teachers should not only present reading strategies, but should also explain and demonstrate how and why they are used. More attention should be given to strategies that are usually needed for reading academic materials. In addition, it is highly recommended that teachers provide their students with different opportunities to practice using these strategies and monitor their use.

For reading strategy instruction to be effective, great emphasis should be given to reading self-efficacy. Raising students' self-efficacy beliefs makes them use reading strategies more frequently and effectively. Therefore, it is important for teachers to consider the factors that affect students' self-efficacy to help them develop strong beliefs of their reading ability. At beginning stages, teachers can give students reading tasks that are easy to control, escalating to more difficult ones gradually. In doing so, students can see that they are able to successfully process the information of these reading tasks; hence, their reading self-efficacy beliefs will increase. Furthermore, teachers should create an enjoyable and encouraging atmosphere. They must provide students with positive feedback appropriate to their reading achievements. They should also encourage the students, reminding them that they can achieve comprehension in reading if they just believe in their reading ability and work hard. Encouraging students increases 
their self-efficacy and sustains their motivation and persistence, especially when they face difficulties in reading. In addition, students must be given the opportunity to observe models of their peers performing reading tasks successfully. In this way, students can develop beliefs in their reading ability by realizing that they can succeed, too.

Zainab Alsuhaibani

College of Languages and Translation

Imam Mohammad Ibn Saud Islamic University

Saudi Arabia

alsuhaibani.z@gmail.com 


\section{References}

Al-Nujaidi, Abdulkarim. (2003). The relationship between vocabulary size, reading strategies, and reading comprehension of EFL learners in Saudi Arabia. Unpublished $\mathrm{PhD}$ Dissertation, Oklahoma State University, Stillwater, United States.

Al-Onazi, Zaha. (2011). The effect of reciprocal teaching on enhancing Saudi EFL college students' reading comprehension and metacognitive awareness of reading strategies. Unpublished MA Thesis, King Saud University, Riyadh.

Abidin, Mohammad. (2012). 'Collaborative strategic reading within cognitive and metacognitive strategies perspectives'. International Journal of Humanities and Social Science, 4 (1): 61-69.

Afflerbach, Peter, Dvaid Pearson and Scott Paris. (2008). 'Skills and strategies: Their differences, their relationships, and why it matters'. In Kouider Mokhtari and Ravi Sheorey (eds.), Reading Strategies of First- and SecondLanguage Learners: See How They Read (pp. 11-24). Norwood, Massachusetts: Christopher-Gordon Publisher.

Alsheikh, Negmeldin. (2011). 'Three readers, three languages, three texts: The strategic reading of multilingual and multiliterate readers'. The Reading Matrix, 11 (1):34-53.

Anderson, Neil. (1999). 'Exploring second language reading: Issues and strategies'. The Electronic Journal for English as a Second Language, 4 (1). http://www.tesl-ej.org/wordpress/issues/volume4/ej13/ej13r7/ (Retrieved on 13 August, 2018).

Arum, Ade Sukma. (2018). 'Gender, self-efficacy and language learning strategies in reading: How two factors of individual differences work along in EFL male and female students'. IOSR Journal of Humanities and Social Science, 23 (4): 1-9.

Askar, Petek. And David Davenport. (2009). 'An Investigation of factors related to self-efficacy for Java programming among engineering students'. The Turkish Online Journal of Educational Technology (TOJET), 8 (1), 2632.

Atari, Omar. (2003). 'A preliminary investigation of Saudi students' strategies in EFL reading'. International Journal of Arabic-English Studies, 4 (1): 191210.

Bandura, Albert. (1986). Social Foundations of Thought and Action: A social Cognitive Theory. Englewood Cliff, NJ: Prentice Hall.

Bandura, Albert. (1997). Self-efficacy: The Exercise of Control: New York: Freeman.

Bong, Mimi. (2008). 'Effects of parent-child relationships and classroom goal structures on motivation, help-seeking avoidance, and cheating'. Journal of Experimental Education, 76 (2): 191-217. 
Camps, Joaquim. (2003). 'Concurrent and retrospective verbal reports as tools to better understand the role of attention in second language tasks'. International Journal of Applied Linguistics, 13 (2): 201-221.

Chastain, Kenneth. (1988). Developing Second Language Skills: Theory and Practice ( $3^{\text {rd }}$ ed.). California: Hartcourt Brace Jovanovich.

Creswell, John and Vicki Clark. (2010). Designing and Conducting Mixed Methods Research $\left(2^{\text {nd }}\right.$ ed.). California: Sage Publication.

Dhanapala, Kusumi. (2010). 'Sri lankan university students' metacognitive awareness of L2 reading strategies. Journal of International Development and Cooperation, 16 (1): 65-82.

Elashhab, Seham. (2008). EFL reading strategies of main idea comprehension and identification: Awareness and use of Arabic speaking university students. Unpublished PhD Dissertation, University of Ottawa, Canada.

Fan, Weihua. And Cathy Williams. (2009). 'The effects of parental involvement on students' academic self-efficacy, engagement and intrinsic motivation'. Educational Psychology, 30 (1): 53-74

Ghonsooly, Behzad and Majid Elahi. (2011). 'Learners' self-efficacy in reading and its relation to foreign language reading anxiety and reading achievement'. Journal of English Language Teaching and Learning 53 (217).

http://www.sid.ir/en/VEWSSID/J_pdf/1323201021703.pdf (Retrieved on 2 February, 2019).

Goodman, Kenneth. (1976). 'Reading: A psycholinguistic guessing game'. In Harry Singer and Robert Ruddell (eds.), Theoretical Models and Processes of Reading ( $2^{\text {nd }}$ ed., pp. 497-508). Newark, DE: International Reading Association.

Gough, Phillip. (1972). 'One second of reading'. In James Kavanagh and Ignatius Mattingly (eds.), Language by Ear and by Eye (pp. 331-358). Cambridge, Mass: MIT Press Grabe.

Grabe, William. (2009). Reading in a Second Language: Moving from Theory to Practice. New York: Cambridge University Press.

Grabe, William and Fredrika Stoller. (2011). Teaching and Researching Reading $\left(2^{\text {nd }}\right.$ ed). Harlow: Pearson Education.

Hales, Todd. (2005). Animal communication. http://www.algebralab.org/passage/passage.aspx?file=biology_animalcomm unication.xml

Heidari, Farrokhlagha, Mehri Izadi and Mansooreh Ahmadian. (2012). 'The relationship between Iranian EFL learners' self-efficacy beliefs and use of vocabulary learning strategies'. English Language Teaching, 5 (2): 174182.

Kamran, Saeedeh. (2012). 'Does reading strategy use predict and correlate with reading achievement of EFL learners?'. International Journal of Research Studies in Language Learning, 2 (2): 29-38. 
Li, Yusheng and Chuang Wang. (2010). 'An empirical study of reading selfefficacy and the use of reading strategies in the Chinese EFL context'. The Asian EFL Journal Quarterly, 12 (2): 144-162.

Malcolm, Diane. (2012). 'Changes in awareness of academic reading strategies among Arab medical students'. Arab World English Journal, 3(2): 4-30.

Margolis, Howard. And Patrick McCabe. (2006). 'Improving self-efficacy and motivation: What to do, what to say'. Intervention in School and Clinic, 41 (4): 218-227.

Matar, A. (1990). The relationship between reading strategies and reading comprehension among EFL Saudi university students. Unpublished master's thesis, King Saud University, Riyadh.

McCrudden, Matthe, Peggy Perkins and LeAnn Putney. (2005). 'Self-efficacy and interest in the use of reading strategies'. Journal of Research in Childhood Education, 20 (2): 119-131.

McShane, Susan. (2005). Applying Research in Reading Instruction for Adults: First Steps for Teachers. Washington, DC: National Institute for Literacy.

Mebarki, Zahia. (2011). 'Vocabulary knowledge and reading comprehension'. International Journal of Arabic-English Studies, 12 (1):131-154.

Mills, Nicole, Frank Pajares and Carol Herron. (2006). 'A reevaluation of the role of anxiety: Self-efficacy, anxiety, and their relation to reading and listening proficiency'. Foreign Language Annals, 39 (2): 276-294.

Mokhtari, Kouider and Ravi Sheorey. (2002). 'Measuring ESL students' awareness of reading strategies'. Journal of Developmental Education, 25 (3): $2-10$.

Morali, Gürkan. (2019). 'Examination of the reading self-efficacy of learners of Turkish as a foreign language regarding some variables'. International Journal of Instruction, 12 (1): 1445-1458.

Naseri, Mahdieh and Elaheh Zaferanieh. (2012). 'The relationship between reading self-efficacy beliefs, reading strategy use and reading comprehension level of Iranian EFL learners'. World Journal of Education, 2 (2): 64-75.

Oxford, Rebecca and Jill Shearin. (1994). 'Language learning motivation: Expanding the theoretical framework'. The Modern Language Journal, 78 (1): $12-25$.

Park, Yonghyo. (2010). Korean EFL college students' reading strategy use to comprehend authentic expository/technical texts in English. Unpublished $\mathrm{PhD}$ Dissertation, University of Kansas, USA.

Purewal, Suman. (2008). Synthetic phonics and the literacy development of second language young learners. Unpublished MA Thesis, University of Leeds, UK

Rachmajanti, Sri and Uning Musthofiyah. (2017). 'The Relationship between reading self-efficacy, reading attitude and EFL reading comprehension based on gender difference'. Journal of English Language, Literature, and Teaching, 1(1): 20-26. 
Rahimi, Ali and Atiyah Abedini. (2009). 'The interface between EFL learners' self-efficacy concerning listening comprehension and listening proficiency'. Novitas-Royal, 3(1): 14-28.

Randall, Ayesha. (2008). The effects of reading self-efficacy, expectancy-value, and metacognitive self-regulation on the achievement and persistence of community college students enrolled in basic skills reading courses. Unpublished PhD Dissertation, University of Southern California, Los Angeles.

Rastegar, Ehsan, Mehrabi Kermani and Massoud Khabir. (2017). 'The relationship between metacognitive reading strategies use and reading comprehension achievement of EFL learners'. Open Journal of Modern Linguistics, 7 (2): 65-74.

Raoofi, Saeid, Bee Tan and Swee Chan. (2012). 'Self-efficacy in second/foreign language learning contexts'. English Language Teaching, 5 (11): 60-73.

Rumelhart, David. (1994). 'Toward an interactive model of reading'. In Robert Ruddell, Martha Ruddell and Harry Singer (eds.), Theoretical Models and Processes of Reading (pp. 864-894). Newark, DE, US: International Reading Association.

Sadeghi, Karim. (2007). 'The key for successful reader-writer interaction: Factors affecting reading comprehension in L2 revisited'. The Asian EFL Journal, 9 (3): 198-220.

Schunk, Dale. (1995). 'Self-efficacy and education and instruction'. In James Maddux (ed.). Self-efficacy, Adaptation, and Adjustment: Theory, Research, and Adaptation (pp. 281-303). New York: Plenum Press.

Sheorey, Ravi and Kouider Mokhtari. (2001). 'Differences in the metacognitive awareness of reading strategies among native and non-native readers'. System, 29 (4): 431-449.

Smith, Frank. (2004). Understanding Reading: A Psycholinguistic Analysis of Reading and Learning to Read (6 $6^{\text {th }}$ ed.). Mahwah, NJ: Lawrence Erlbaum Associates

Snow, Catherine and Anne Sweet. (2003). 'Reading for comprehension'. In Anne Sweet and Catherine Snow (eds.), Rethinking Reading Comprehension (pp.1-11). New York: The Guilford Press.

Sun, Li-En. (2010). A study of the effects of reciprocal teaching as a reading strategy instruction on metacognitive awareness, self-efficacy, and English reading comprehension of EFL junior high school students. Unpublished PhD Dissertation, La Sierra University, USA.

Temur, Turan and Ozge Bahar. (2011). 'Metacognitive awareness of reading strategies of Turkish learners who learn English as a foreign language'. European Journal of Educational Studies, 3 (2): 421-427.

Wenden, Anita and Joan Rubin. (1987). Learner Strategies in Language Learning. New Jersey: Prentice Hall. 
Zare, Mostafa and Sajad Mobarakeh. (2011). 'The relationship between selfefficacy and use of reading strategies: The case of Iranian senior high school students'. Studies in Literature and Language, 3 (3): 98-105. 